\title{
PHYSIOLOGICAL QUALITY AND ANTIOXIDANT ENZYMATIC ACTION IN SUNFLOWER SEEDS EXPOSED TO DETERIORATION ${ }^{1}$
}

\author{
THAÍS DE CASTRO MORAIS ${ }^{2}$, DENISE CUNHA FERNANDES DOS SANTOS DIAS ${ }^{2}$, DANIEL TEIXEIRA \\ PINHEIRO $^{2 *}$, GUILHERME FONTES VALORY GAMA ${ }^{2}$, LAÉRCIO JUNIO DA SILVA ${ }^{2}$
}

\begin{abstract}
This work aimed to evaluate the physiological and biochemical changes resulting from controlled deterioration in different lots of sunflower seeds. Two sunflower seed lots of the cultivar Hélio 253 were subjected to simulated deterioration, using the accelerated aging test methodology $\left(41{ }^{\circ} \mathrm{C}\right.$ and $\left.100 \% \mathrm{RH}\right)$ for $0,48,72$, and $96 \mathrm{~h}$. Then, the seeds were subjected to the tests of germination, first germination count, seedling length and dry matter, emergence, accelerated aging, electrical conductivity, and total seedling length. The antioxidant activity was evaluated through the enzymes superoxide dismutase (SOD), ascorbate peroxidase (APX), and peroxidase (POX) at 0, 2, 4, and 6 days after sowing. Deterioration caused a reduction in the germination and vigor of the seeds, mainly in the lot with lower initial vigor and for the longest exposure times (72 and 96 h). For both lots, reductions in SOD activity and increases in POX and APX were observed during seed germination, mainly after $48 \mathrm{~h}$ of exposure to aging deterioration. Peroxidase enzymes are activated in deteriorated and non-deteriorated sunflower seeds, mainly after two days of germination.
\end{abstract}

Keywords: Helianthus annuus L. Antioxidant enzymes. Accelerated aging. Seed vigor.

\section{QUALIDADE FISIOLÓGICA E AÇÃO ENZIMÁTICA ANTIOXIDANTE EM SEMENTES DE GIRASSOL EXPOSTAS À DETERIORAÇÃO}

RESUMO - O objetivo do trabalho foi avaliar as alterações físiológicas e bioquímicas decorrentes da deterioração controlada em diferentes lotes de sementes de girassol. Foram utilizados dois lotes de sementes da cultivar Hélio 253, condicionados à deterioração simulada, utilizando-se a metodologia do teste de envelhecimento acelerado conduzido $\left(41^{\circ} \mathrm{C}\right.$ e $100 \%$ UR) por 0, 48, 72 e $96 \mathrm{~h}$. Em seguida, as sementes foram submetidas aos testes de germinação, primeira contagem de germinação, comprimento e matéria seca de plântulas, emergência, envelhecimento acelerado e condutividade elétrica. A avaliação da atividade antioxidante foi feita através das enzimas superóxido dismutase (SOD), ascorbato peroxidase (APX) e peroxidase $(\mathrm{POX})$ aos $0,2,4$ e 6 dias após a semeadura. A deterioração provocou redução na germinação e no vigor das sementes, principalmente no lote de menor vigor inicial e nos maiores tempos de exposição (72 e 96 h). Para ambos os lotes, foram observadas reduções da atividade da SOD e aumento da POX e APX durante a germinação das sementes, sobretudo a partir de $48 \mathrm{~h}$ de exposição ao envelhecimento. As enzimas peroxidases são ativadas em sementes deterioradas e não deterioradas de girassol, principalmente após dois dias de germinação.

Palavras-chave: Helianthus annuus L. Enzimas antioxidantes. Envelhecimento acelerado. Vigor de sementes.

\footnotetext{
${ }^{*}$ Corresponding author

${ }^{1}$ Received for publication in 09/04/2020; accepted in 03/04/2021.

Paper extracted from the master dissertation of the first author.

${ }_{2}^{2}$ Agronomy Department, Universidade Federal de Viçosa, Viçosa, MG, Brazil; thaiscastro89@gmail.com - ORCID: 0000-0003-3705-8591, dcdias@ufv.br - ORCID: 0000-0002-0596-2490, pinheiroagroufv@gmail.com - ORCID: 0000-0002-8060-8790, guilhermefontes.gama@gmail.com - ORCID: 0000-0002-6685-7969, laercio.silva@ufv.br - ORCID: 0000-0001-7202-0420.
} 


\section{INTRODUCTION}

The world production of sunflower (Helianthus annuus L.) exceeds 50 million tons per year, making it one of the most important oilseed crops produced at the global level (FAOSTAT, 2020). Given this scenario, the demand for highquality seeds is increasing and involves a series of genetic, physical, physiological, and sanitary attributes that influence germination capacity and the development of vigorous plants in the field (MARCOS-FILHO, 2016).

High-quality seeds (especially of cultivated species) can be classified as those that have high germination capacity combined with high vigor, which results in uniform establishment of seedlings even under adverse conditions (FINCH-SAVAGE; BASSEL, 2016; MARCOS-FILHO, 2016). These conditions, such as high temperatures and high relative humidity, intensify the deterioration process, which involves a series of physiological, biochemical, physical, and cytological changes that contribute to the reduction of seed quality (MARCOS-FILHO, 2016; EBONE; CAVERZAN; CHAVARRIA, 2019).

The process of seed deterioration compromises several important cellular events related to oxidative stress, which is characterized by the imbalance between the antioxidant mechanisms (enzymatic and non-enzymatic) and the concentration of reactive oxygen species (ROS) at toxic levels (MITTLER, 2017; NOCTOR; REICHHELD; FOYER, 2018). Therefore, the low capacity of protection against excess ROS leads to physiological imbalances and increased respiration, favoring the loss of vigor and viability of seeds (EBONE; CAVERZAN; CHAVARRIA, 2019). In this context, the action of antioxidant enzymes (especially in orthodox species), such as superoxide dismutase (SOD), peroxidases (POX), and ascorbate peroxidase (APX), and non-enzymatic mechanisms play important roles in controlling oxidative stress and assist in the normal functioning of plant cells even under stress conditions (EBONE; CAVERZAN; CHAVARRIA, 2019; KAPOOR et al., 2019).

Due to the high lipid content and, consequently, higher peroxidation, the seeds of sunflower and other oilseed crops, such as soybean (MIN et al., 2017) and oilseed rape (BONIECKA et al., 2019), are cited as sensitive to deterioration. In sunflower seeds subjected to deterioration by artificial aging, there were reductions in germination and vigor, in addition to greater lipid peroxidation and reduction in the activity of antioxidant enzymes (BAILLY et al., 1996). Thus, when stored (especially under inadequate conditions), sunflower seeds undergo a process of deterioration, showing a significant reduction in physiological quality, enzymatic activity, and lipid content (ABREU et al.,
2013). Morscher et al. (2015) evaluated antioxidant profiles in sunflower seeds subjected to controlled deterioration and observed, in general, the loss of viability associated with oxidative and protein changes in the seeds.

However, studies on the effects of deterioration on sunflower seeds generally do not consider the evaluation of different lots, seeking to associate physiological and antioxidant enzymatic mechanisms as a function of the initial level seeds vigor. Such information can bring important answers and constitute an interesting tool to monitor the deterioration of seeds of this species.

Thus, the aim was to evaluate the physiological potential and changes in the antioxidant enzymatic system resulting from controlled deterioration in lots of sunflower seeds with different vigor levels.

\section{MATERIAL AND METHODS}

The study was conducted at the Seed Laboratory of the Department of Agronomy of the Federal University of Viçosa, located in Viçosa, Minas Gerais, Brazil. Sunflower seeds from two lots of the sunflower cultivar Hélio 253, provided by HELIAGRO, were used in the experiment. This cultivar was chosen because it has wide environmental adaptation, good resistance to lodging, and high yield. Initially, the seeds of each lot were evaluated for physiological quality through different tests.

The germination test was conducted with eight replicates of 25 seeds according to Brasil (2009), with counts of normal seedlings at four (first germination count) and 10 days after sowing (DAS), with the results expressed as a percentage of normal seedlings.

For seedling length (shoot and root), four replicates of 10 seeds were arranged on rolls of moistened paper towel and kept in BOD chamber at $25^{\circ} \mathrm{C}$. At $10 \mathrm{DAS}$, the total length of the normal seedlings was measured, expressed in $\mathrm{cm}$ seedling ${ }^{-1}$, and the dry matter was determined after keeping the material in a forced air circulation oven at $75{ }^{\circ} \mathrm{C}$ for $72 \mathrm{~h}$, with the results expressed in $\mathrm{mg}$ seedling ${ }^{-1}$.

The seedling emergence test was conducted in a greenhouse (average temperature of $25.3{ }^{\circ} \mathrm{C}$ and average relative humidity of 54\%) in trays with cells $\left(90 \mathrm{~cm}^{3}\right)$ containing as substrate medium-textured soil and sand in the proportion of $2: 1$. Four replicates of 50 seeds were sown at $1 \mathrm{~cm}$ depth and daily counts were performed until stabilization. Then, the emergence percentage and emergence speed index (ESI) were calculated (MAGUIRE, 1962).

For the accelerated aging test, approximately 250 seeds were distributed on a screen fixed onto gerbox-type boxes containing, at the bottom, $40 \mathrm{~mL}$ of distilled water. The boxes were closed and kept in 
a BOD incubator at $41{ }^{\circ} \mathrm{C}$ for 48 hours (MARCOSFILHO, 2020). After this period, the percentage of normal seedlings was evaluated at 4 DAS.

The electrical conductivity test was performed with four replicates of 50 seeds and according to the methodology proposed by Szemruch et al. (2015), with the results expressed in $\mu \mathrm{S} \mathrm{cm}^{-1} \mathrm{~g}^{-1}$.

After the initial characterization, the seeds of each lot were subjected to deterioration. Approximately 250 seeds were subjected to the methodology described by Marcos-Filho (2020) for the accelerated aging test $\left(41{ }^{\circ} \mathrm{C}\right.$ and $100 \%$ relative humidity) and maintained under these conditions for 48,72 , and 96 hours. For the control treatment $(0 \mathrm{~h})$, the seeds were not subjected to aging. Subsequently, the seeds were placed in a laboratory environment until they reached the hygroscopic equilibrium (approximately 15\% humidity). Following the methodologies described above for the initial characterization of the lots, the seeds of each treatment were evaluated for germination, first count, electrical conductivity, and seedling length.

For the evaluation of the activity of antioxidant enzymes, the seeds of each deterioration treatment were placed to soak on a moistened paper towel, according to the methodology used for the germination test (BRASIL, 2009), at $25^{\circ} \mathrm{C}$, for 0,2 , 4 and 6 days. In treatment 0 (control), the seeds were kept under the same conditions, soaking for $12 \mathrm{~h}$ to activate their metabolism. Subsequently, the embryos were frozen in liquid nitrogen. The activities of the enzymes superoxide dismutase (SOD), with results expressed in $\mathrm{U} \mathrm{min}^{-1} \mathrm{mg}^{-1}$ protein (BEAUCHAMP; FRIDOVICH, 1971), peroxidase (POX), with results expressed in

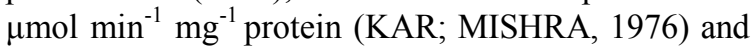
ascorbate peroxidase (APX), with results expressed in $\mathrm{nmol} \mathrm{min} \mathrm{mg}^{-1}$ protein (NAKANO; ASADA, 1981), were determined by obtaining the crude extracts by macerating $0.3 \mathrm{~g}$ of embryos in liquid nitrogen, followed by the addition of $2 \mathrm{~mL}$ of extraction medium, potassium phosphate buffer $(0.1$ $\mathrm{M}, \mathrm{pH}$ 6.8), containing ethylenediaminetetraacetic acid (EDTA) (0.1 mM), phenyl methyl sulfonyl fluoride (PMSF) (1.0 $\mathrm{mM}) \quad$ and polyvinylpolypyrrolidone (PVPP) $1 \%(\mathrm{p} / \mathrm{v})$. The homogenate was centrifuged at $19,000 \mathrm{~g}$ for $15 \mathrm{~min}$., at $4{ }^{\circ} \mathrm{C}$.

Protein content was determined using bovine serum albumin (BSA) as standard, according to the methodology proposed by Bradford (1976), and the results were expressed in $\mathrm{mg} \mathrm{g}^{-1}$ of fresh matter and used to calculate the activity of the antioxidant enzymes.

The experiment was installed in a completely randomized design (CRD) with four replicates. The data obtained in the tests of germination, first count, electrical conductivity, and total seedling length were analyzed in a 2 (lots) x 4 (deterioration times) factorial scheme. The means were fitted with regression equations and the regression coefficients were evaluated by the t-test at $5 \%$ probability level. Enzymatic activity data were analyzed in a 2 (lots) $\mathrm{x}$ 4 (deterioration times) $\times 4$ (days after sowing - DAS) factorial scheme and were represented by the mean, with the respective standard deviation. A multivariate principal component analysis (PCA) was also performed for all combinations between the variables analyzed. An " $n$ x p" matrix was obtained, where " $n$ " corresponds to the number of treatments ( $\mathrm{n}=8$ ) and " $\mathrm{p}$ " corresponds to the number of variables analyzed $(\mathrm{p}=7)$. Eigenvalues and eigenvectors were calculated from the covariance matrices and plotted in two-dimensional graphs (category ordering diagram and correlation circle). R statistical software environment was used in all analyses (R CORE TEAM, 2020).

\section{RESULTS AND DISCUSSION}

Based on the characterization of the initial quality of the lots, there was no significant difference between the lots regarding germination, both with values higher than $90 \%$ and also in terms of seedling length and dry matter. Although there were no differences between the lots regarding seedling growth, the superiority of lot 1 was noted by the tests of first germination count, accelerated aging, emergence, ESI, and electrical conductivity (Table 1).

The results indicate faster germination of seeds in lot 1 , besides a greater tolerance to stress conditions, guaranteed by a greater organization of cell membranes. The electrical conductivity test makes it possible to infer the integrity of membranes and is considered to be highly efficient in programs for quality control of sunflower seeds. Szemruch et al. (2015) mention that sunflower lots with high vigor have conductivity values $<70 \mu \mathrm{s} \mathrm{cm}^{-1} \mathrm{~g}^{-1}$ (as observed for lot 1), while medium-vigor lots have values between 70 and $110 \mu \mathrm{s} \mathrm{cm}^{-1} \mathrm{~g}^{-1}$ (as observed for lot 2).

These results are reinforced by the higher emergence capacity of lot 1 , which had a higher emergence percentage and emergence speed index (ESI) compared to lot 2 (Table 1). In general, the rapid and uniform emergence of seedlings depends on factors such as the mobilization of reserves and hormonal balance (DE WIT; GALVÃO; FANKHAUSER, 2016). In epigeal species such as sunflower, seeds with higher vigor have a greater capacity of control over these and other cellular processes, which in turn will be determinant in the formation of the hypocotyl hook to disrupt soil surface (FINCH-SAVAGE; BASSEL, 2016; PHAM et al., 2018). 
Table 1. Characterization of the physiological potential of seeds of two sunflower lots, cultivar Hélio 253.

\begin{tabular}{cccccc}
\hline Lot & $\begin{array}{c}\text { Germination } \\
(\%)\end{array}$ & $\begin{array}{c}\text { FGC } \\
(\%)\end{array}$ & $\begin{array}{c}\text { AA } \\
(\%)\end{array}$ & $\begin{array}{c}\text { SL } \\
\left(\mathrm{cm} \mathrm{seedling}^{-1}\right)\end{array}$ & $\begin{array}{c}\text { RL } \\
\left(\mathrm{cm} \mathrm{seedling}^{-1}\right)\end{array}$ \\
\hline 1 & $95 \mathrm{~A}$ & $91 \mathrm{~A}$ & $92 \mathrm{~A}$ & $11.9 \mathrm{~A}$ & $13.7 \mathrm{~A}$ \\
2 & $91 \mathrm{~A}$ & $80 \mathrm{~B}$ & $73 \mathrm{~B}$ & $10.1 \mathrm{~A}$ & $12.4 \mathrm{~A}$ \\
\hline $\mathrm{CV}(\%)$ & 3.0 & 5.5 & 11.3 & 18.0 & 24.3 \\
\hline \multirow{2}{*}{ Lot } & $\mathrm{SDM}$ & $\begin{array}{c}\text { RDM } \\
\left(\mathrm{mg} \mathrm{seedling}^{-1}\right)\end{array}$ & $\begin{array}{c}\text { Emergence } \\
(\%)\end{array}$ & ESI & $\begin{array}{c}\left.\mathrm{EC}^{-1}\right) \\
\left(\mu \mathrm{cm}^{-1} \mathrm{~g}^{-1}\right)\end{array}$ \\
\hline 1 & $45.0 \mathrm{~A}$ & $15.9 \mathrm{~A}$ & $100 \mathrm{~A}$ & $11.1 \mathrm{~A}$ & $65.2 \mathrm{~A}$ \\
\hline $\mathrm{CV}(\%)$ & $44.8 \mathrm{~A}$ & $12.4 \mathrm{~A}$ & $86 \mathrm{~B}$ & $8.9 \mathrm{~B}$ & $75.7 \mathrm{~B}$ \\
\hline
\end{tabular}

First germination count (FGC); Accelerated aging (AA); Shoot length (SL); Root length (RL); Shoot dry matter (SDM); Root dry matter (RDM); Emergence speed index (ESI); Electrical conductivity (EC); Coefficient of variation (CV). Means followed by the same letter in the column do not differ from each other by $\mathrm{F}$ test $(\mathrm{P}<0.05)$.

There was a significant interaction between the factors lot and time of exposure to simulated deterioration for all variables analyzed. The percentage and speed of germination of sunflower seeds were reduced with increasing time of exposure to deterioration. Due to the lower initial vigor, lot 2 showed a marked reduction in germination percentage and the first germination count, already in the first $48 \mathrm{~h}$ of exposure to deterioration (Figure 1A and $1 \mathrm{~B})$.
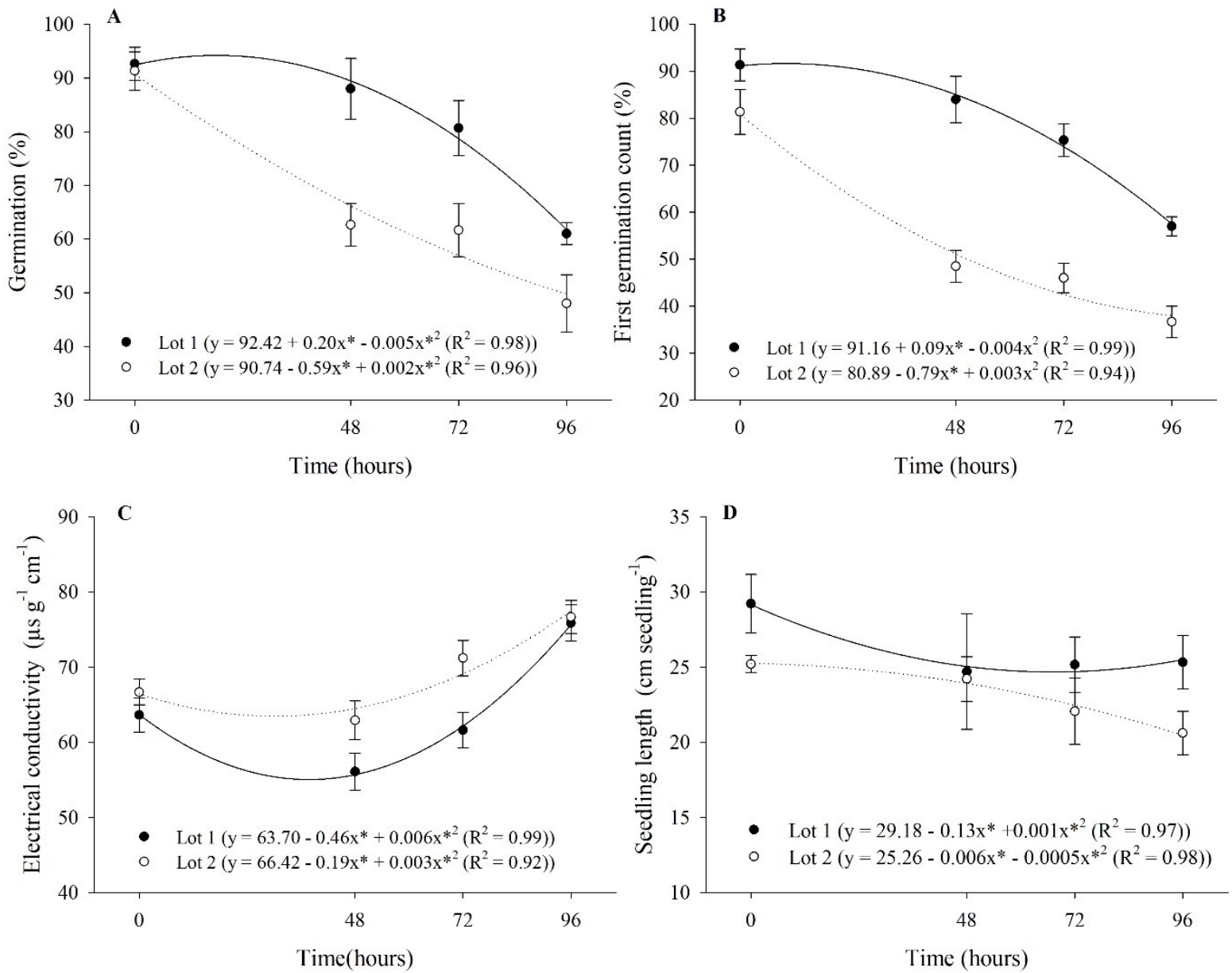

Figure 1. Germination (A), first germination count (B), electrical conductivity (C) and seedling length (D) of two lots of sunflower seeds exposed to different periods of accelerated aging. Points represent the means of four replicates and bars correspond to the standard deviation. *: Significant at 5\% level by t-test. 
It is important to consider that the minimum percentage of germination established by Brazilian legislation for the commercialization of sunflower seeds is $75 \%$ (BRASIL, 2013). In this context, it is observed that lot 1 (high vigor) showed a value lower than this only for the longest time of exposure to aging (96 h). In lot 2 (medium vigor), values lower than $70 \%$ germination were observed from the treatment of $48 \mathrm{~h}$ (Figure 1A and 1B).

The process of seed deterioration causes damage to the membrane system, mainly caused by the attack of reactive oxygen species when above basal levels (SAHU et al., 2017). In this context, the deterioration caused a significant increase in the electrical conductivity of both lots, mainly after $72 \mathrm{~h}$ of exposure. As occurred for germination, this result was more significant in lot 2 (medium vigor), which, despite that, reached a value similar to that of lot 1 (high vigor) at the maximum exposure time (96 h) (Figure 1C). Therefore, the membrane system of the seeds was one of the targets of the deterioration process, considerably increasing the leakage of cell content.

During deterioration, there is an excessive increase in the respiratory rate of seeds, which in turn contributes to greater degradation and less mobilization of reserves to the embryonic axis (RATAJCZAK et al., 2019). In this context, the growth of seedlings from the two analyzed lots was reduced by deterioration, with significant differences between lots with $96 \mathrm{~h}$ of exposure (Figure 1D).

In general, the deterioration process is enhanced by high temperatures and high relative humidity. However, as observed in this study, the initial physiological condition of the seeds also has a significant influence on the rates of deterioration. Reinforcing the importance of the effects observed in the present study, the evaluation of simulated deterioration through accelerated aging also helps in estimating the longevity of seeds during storage, being used in the internal control of companies to evaluate the potential of seed lots (MARCOSFILHO, 2020; OLIVEIRA et al., 2020). In this context, lot 2 (medium vigor) can be classified as of low potential for storage. Abreu et al. (2013) observed that sunflower seeds were sensitive to deterioration during storage, reporting a reduction in germination after four months of conventional storage $\left(18-20{ }^{\circ} \mathrm{C} / 50-70 \% \mathrm{RH}\right)$ and in cold chamber conditions $\left(10{ }^{\circ} \mathrm{C} / 40 \% \mathrm{RH}\right)$.

The sensitivity of sunflower seeds to deterioration is probably also related to high lipid content. In general, oilseed species are susceptible to the lipid peroxidation process and increase the breaking of membrane lipid chains during storage, which in turn intensifies the formation of reactive oxygen species (ROS) at the cellular level (BALESEVIC-TUBIC et al., 2010). Moreover, there is the process of de-esterification of membrane phospholipids, mainly caused by an excess of ROS and which leads to the significant accumulation of free fatty acids (FAAs) (ANJUM et al., 2015). ElMaarouf-Bouteau et al. (2011) mention the relative humidity of $100 \%$ in the accelerated aging test as responsible for the activity of the enzyme lipoxygenase and considerable increase in respiration, which are considered key factors for the reduction in the viability of sunflower seeds. Therefore, these and other cellular events cause excessive concentration of ROS, which can influence not only lipid peroxidation but also enzymatic inactivation, programmed cell death, and mitochondrial dysfunctions (LI et al., 2017).

Through enzymatic analyses, it is possible to observe a similar pattern in the activity of superoxide dismutase (SOD) in lots 1 (high vigor) and 2 (medium vigor). In general, the activity of this enzyme was reduced over the germination time, regardless of the imposed times of exposure to deterioration. Considering the beginning of germination ( 0 days; 12 hours of soaking), the seeds subjected to the longest time of deterioration ( $96 \mathrm{~h}$ ) had lower SOD activity compared to the other treatments (Figure 2A and B).

SOD acts in the first line of defense against oxidative stress, through the dismutation of the superoxide radical $\left(\mathrm{O}_{2}^{-}\right)$to hydrogen peroxide $\left(\mathrm{H}_{2} \mathrm{O}_{2}\right)$, which in turn is less toxic and reactive to cells. The reduction in the activity of this enzyme observed over the germination time in sunflower seeds is probably related to the fact that $\mathrm{O}_{2} .^{-}$is highly unstable and converted rapidly and spontaneously into $\mathrm{H}_{2} \mathrm{O}_{2}$ (MITTLER, 2017). Therefore, this characteristic of $\mathrm{O}_{2} \cdot-$ could have reduced the demand for the action of this enzyme over time due to the higher concentration of $\mathrm{H}_{2} \mathrm{O}_{2}$.

Differently from what was observed for SOD, the activity of the enzyme peroxidase (POX) increased over the germination time in the two evaluated lots (Figure 2C and D). In general, this increase was similar for all treatments $(0,48,72$ and $96 \mathrm{~h}$ of exposure to deterioration), except for the time of $48 \mathrm{~h}$ in lot 2 (medium vigor), at which the activity of this enzyme was higher at 0 and 2 days. Furthermore, this lot only showed a reduction in POX activity at $96 \mathrm{~h}$ (Figure 2D).

The activity of ascorbate peroxidase (APX) for the control $(0 \mathrm{~h})$ and $48 \mathrm{~h}$ treatments showed a pattern similar to that observed for POX over the germination time. The control treatment ( 0 hours) of both lots had an increase in the activity of this enzyme from the second day of germination. Considering the time of $72 \mathrm{~h}$ of exposure to aging in both lots, there were increments of approximately 0.02 and $0.015 \mathrm{nmol} \mathrm{min}^{-1} \mathrm{mg}^{-1}$ protein for lots 1 and 2 , respectively, until the fourth day, with a reduction 
until the sixth day. Except for the control treatment $(0 \mathrm{~h})$, the highest activities of APX were observed in the seeds of lot 2 (medium vigor) subjected to 96 hours until the fourth day of germination, with a reduction of approximately $0.05 \mathrm{nmol} \mathrm{min} \mathrm{mg}^{-1}$ protein on the sixth day (Figure 2E and F).
LOT 1
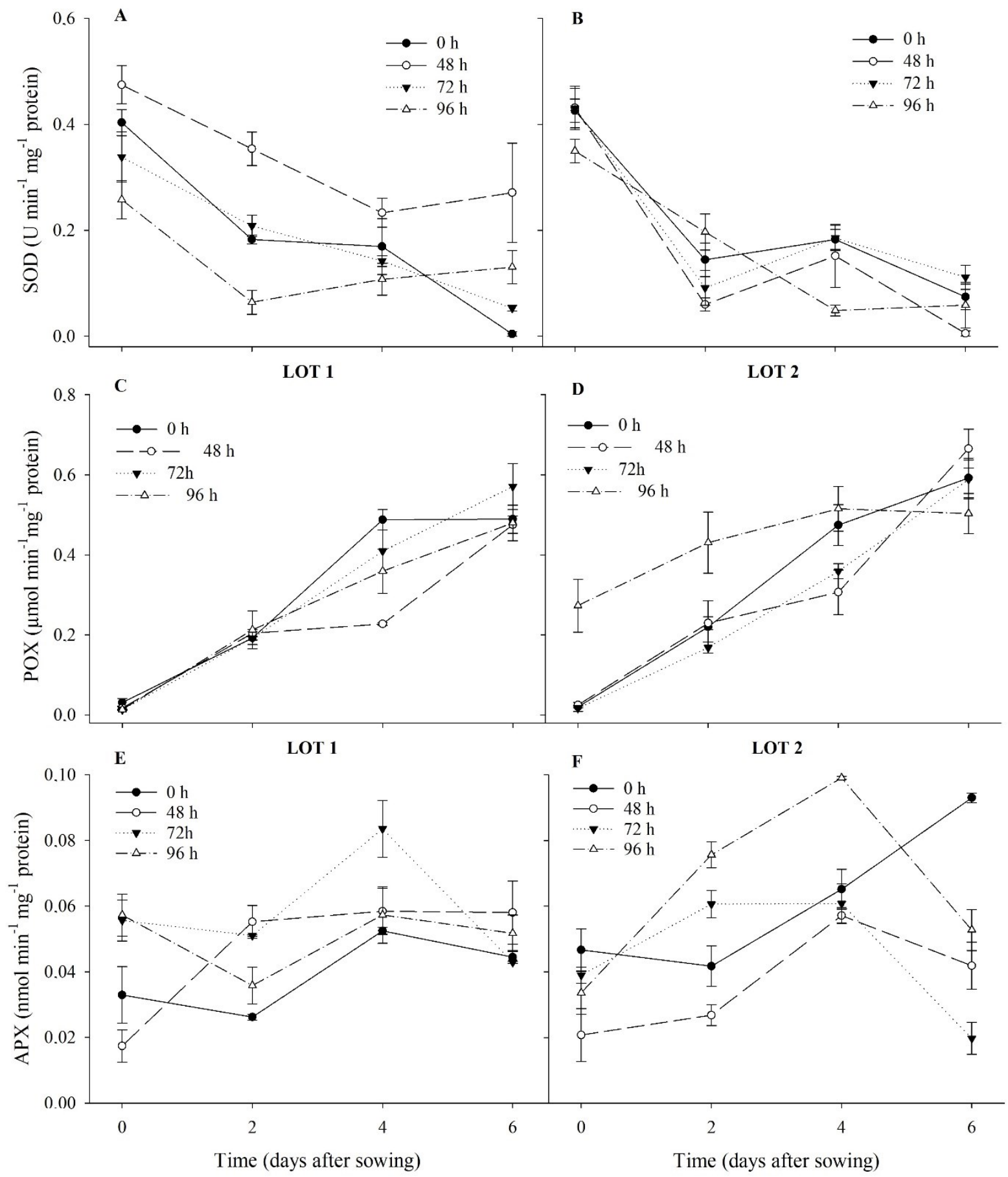

LOT 2
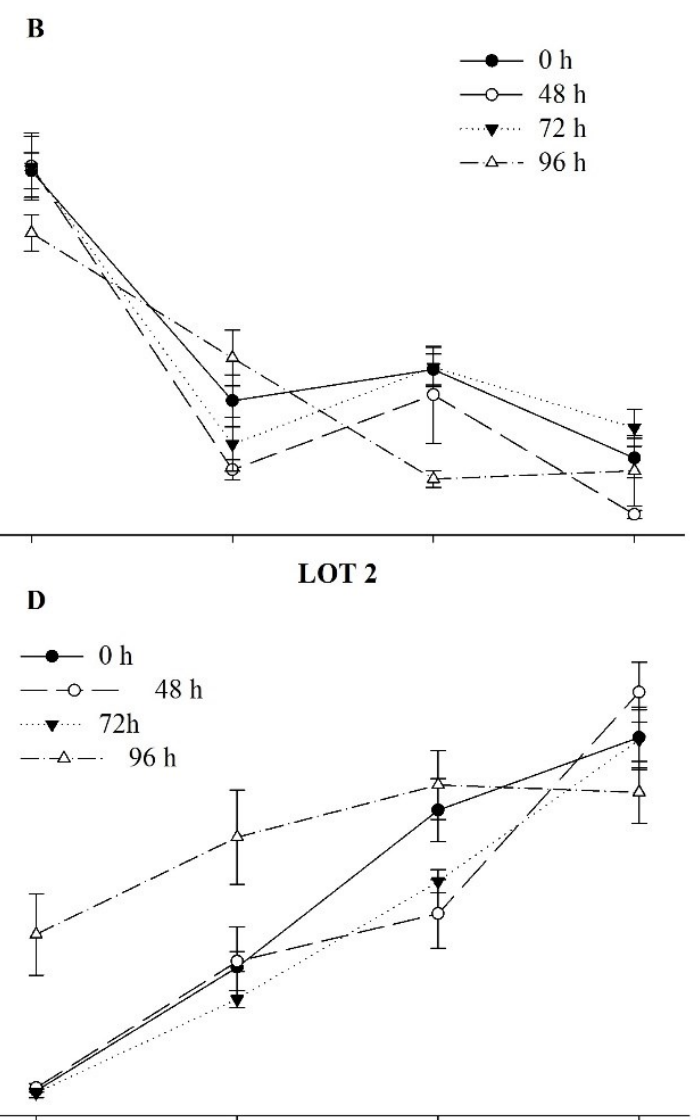

in the activity of these enzymes over germination time indicate greater demand due to the higher concentration of $\mathrm{H}_{2} \mathrm{O}_{2}$. It is important to highlight

Figure 2. Activity of the enzymes superoxide dismutase (SOD) (A and B), peroxidase (POX) (C and D), and ascorbate peroxidase (APX) (E and F) determined at $0,2,4$ and 6 days of germination in two lots of sunflower seeds exposed to deterioration by accelerated aging. Bars: Standard deviation.

POX and APX enzymes are part of a broad group of peroxidases that neutralize hydrogen peroxide $\left(\mathrm{H}_{2} \mathrm{O}_{2}\right)$. Therefore, the observed increments 
that $\mathrm{H}_{2} \mathrm{O}_{2}$ at basal levels performs important functions in cells, such as cell signaling, reserve mobilization, and others (MITTLER, 2017; FAROOQ et al., 2019). However, considering the significant increase in the activity of POX and APX in seeds subjected to deterioration along with the reduction of physiological quality (Figure 1), the reason may a possible excessive increase in the concentration of $\mathrm{H}_{2} \mathrm{O}_{2}$, above the limit at which these enzymes were able to neutralize.

Oxidative stress caused by deterioration is characterized by the imbalance between reactive oxygen species and antioxidant systems, favoring the occurrence of its numerous deleterious effects at the cellular level (MITTLER, 2017; NOCTOR; REICHHELD; FOYER, 2018). As observed in the control $(0 \mathrm{~h})$ and in the shortest deterioration time $(48 \mathrm{~h})$, an increase in SOD activity is related to higher germination and vigor of sunflower seeds subjected to controlled deterioration, as reported by Sahu et al. (2017) when working with natural aging and controlled deterioration in Neem (Azadirachta indica) seeds. However, differently from what was observed, these same authors mention the higher activity of peroxidases in seeds with higher physiological potential. This highlights the difference in behavior in the antioxidant defense mechanism in different species, initial physiological conditions of the seeds, and levels of deterioration applied.

In general, seeds with low vigor have lower efficiency in neutralizing oxidative stress, which further favors the reduction of their germination and vigor (BAILLY, 2004). As already mentioned, antioxidant enzymes are involved in several functions at the cellular level, such as the mobilization of reserves (intense activity during seedling formation), which may explain the increase in the activity of APX and POX over time. Despite performing these and other important functions, these enzymes are linked to the neutralization of $\mathrm{H}_{2} \mathrm{O}_{2}$. Thus, because few significant differences were observed between the activity of antioxidant enzymes in lots 1 (high vigor) and 2 (medium vigor), the differences in physiological quality may probably be linked to the greater accumulation of $\mathrm{H}_{2} \mathrm{O}_{2}$ in the seeds of lot 2, indicating an imbalance of these products at the cellular level. In sunflower seeds subjected to controlled deterioration, progressive loss of germination capacity combined with a loss of vigor, increase in lipid peroxidation and reduction of SOD activity have been reported (BAILLY et al., 1996), as observed in the present study (Figure 2A and B). In soybean seeds, controlled deterioration caused oxidative stress, which significantly altered the protein profile of the seeds and contributed to the reduction of viability (MIN et al., 2017). In oilseed rape (Brassica napus), artificial aging of seeds caused a reduction of vigor, associated with low DNA synthesis and significant change in the activity of antioxidant enzymes such as SOD and APX (BONIECKA et al., 2019). As observed here, sunflower seeds from the same lots used in this study, but underwater restriction, showed an increase in the activity of POX and APX enzymes over the germination time (MORAIS et al., 2020).

The influence of each variable on the discrimination of the treatments applied in each lot of sunflower seeds subjected to deterioration was analyzed in more detail using principal component analysis (PCA). The first two principal components (PC1 and PC2) combined explained more than $80 \%$ of the total data variation $(\mathrm{PC} 1=56.1 \%$ and $\mathrm{PC} 2=27.5 \%)($ Figure $3 \mathrm{~A})$.

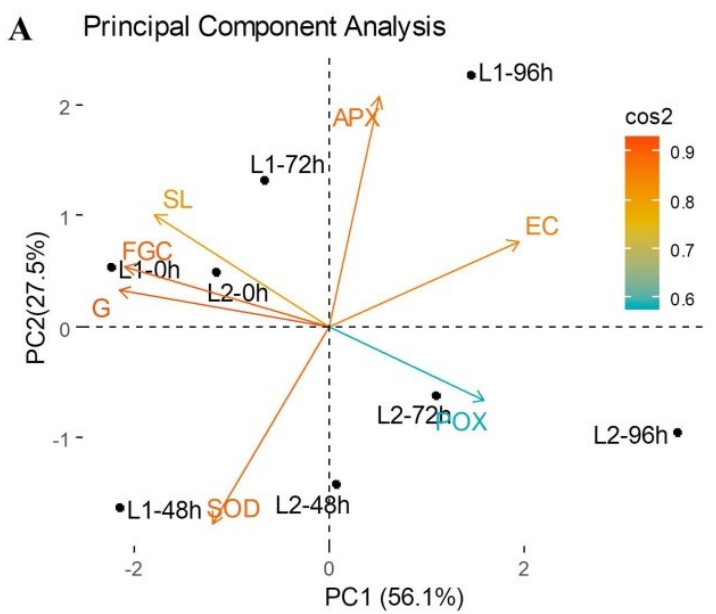

B

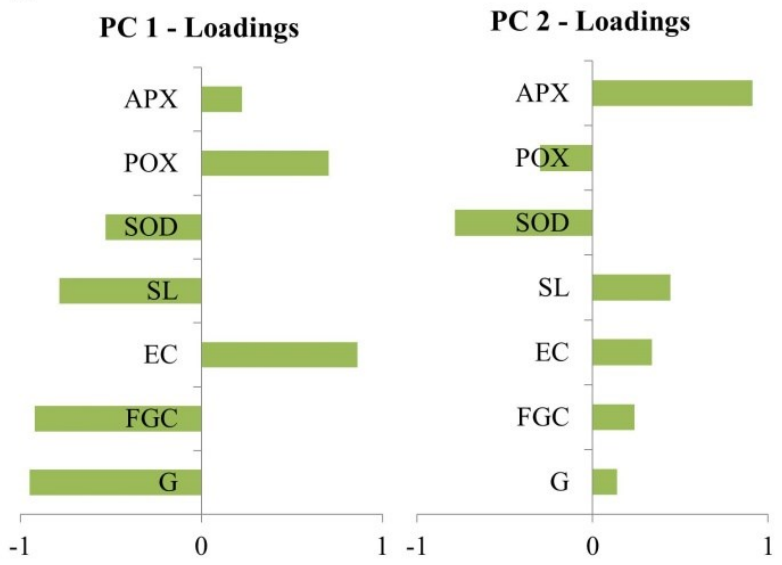

Figure 3. Biplot obtained by principal component analysis (PCA) (A) and vector loadings (B) obtained by the linear combination of physiological and biochemical variables of two lots of sunflower seeds exposed to deterioration. Principal component 1 (PC1); Principal component 2 (PC2); Germination (G); First germination count (FGC); Electrical conductivity (EC); Seedling length (SL); Superoxide dismutase (SOD); Peroxidase (POX); Ascorbate peroxidase (APX). 
It is possible to observe a positioning of the control treatments of the two lots (L1-0h and L2-0h) in $\mathrm{PC} 1-/ \mathrm{PC} 2+$, close to the vectors of the physiological variables: germination $(\mathrm{G})$, first count (FGC), and seedling length (SL) (Figure 3A). Moreover, high contribution loadings of these variables were observed for $\mathrm{PC1}$ (Figure 3B). Therefore, these treatments showed a high correlation with physiological variables, positioning themselves distant from the vectors of the variables superoxide dismutase (SOD), ascorbate peroxidase (APX), peroxidase (POX), and electrical conductivity (EC) (Figure 3A). These results reinforce the higher physiological performance of the seeds of the control treatment $(0 \mathrm{~h}$ of exposure to deterioration) (Figure 1).

On the other hand, both lots subjected to $48 \mathrm{~h}$ of exposure to deterioration were positioned in PC1-/PC2- and PC1+/PC2-, respectively, close to the vector of the SOD variable. Such higher activity of SOD in these treatments indicates the beginning of the antioxidant action by the dismutation of the superoxide radical $\left(\mathrm{O}_{2}^{-}\right)$to hydrogen peroxide $\left(\mathrm{H}_{2} \mathrm{O}_{2}\right)$ in the seeds, mainly for lot 1 (high vigor). On the other hand, opposite directions of the two lots to the SOD vector were observed for the other exposure times (72 and 96 hours) (Figure 3A). This observation reinforces the reduction in SOD activity over germination time, which, among other factors, may be associated with an intense respiratory rate of seedlings, with a reduction in $\mathrm{O}_{2}{ }^{-}$rates and increase of $\mathrm{H}_{2} \mathrm{O}_{2}$, with the continuation of the antioxidant process through peroxidase enzymes (APX and POX), which was indeed observed in the enzymatic analyses (Figure 2).

Considering lot 1 (high vigor), it was possible to observe a positioning of the treatments of 72 (L172h) (PC1-/PC2+) and $96 \mathrm{~h}$ (L1-96h) (PC1+/PC2+) close to the vector of the APX enzyme. Regarding lot 2 (medium vigor), the treatments of 72 (L2-72h) and 96 hours (L2-96h) were allocated in a position opposite to the vectors of physiological quality and close to the vector of the POX enzyme, in PC1+/PC2 - (Figure 3A). Therefore, the higher activity of POX and APX enzymes at the highest times of exposure to deterioration (72 and 96 hours) reinforces the metabolization action of $\mathrm{H}_{2} \mathrm{O}_{2}$. It is worth pointing out that in these treatments ( 72 and $96 \mathrm{~h}$ ), there was a significant reduction in the physiological quality of the seeds of both lots (Figure 1). In this context, there are signs that, despite being active, these enzymes were not able to neutralize a possible excess of $\mathrm{H}_{2} \mathrm{O}_{2}$ at the cellular level.

These deleterious effects caused mainly by longer exposure to deterioration ( $96 \mathrm{~h}$ ) are confirmed in this study even for seeds of high physiological quality (lot 1). The proximity of this treatment (L1$96 \mathrm{~h}$ ) to the vector of the electrical conductivity (EC) variable is observed, with a high loading of contribution to $\mathrm{PC} 2$ (Figure $3 \mathrm{~A}$ and $\mathrm{B}$ ). This observation shows a negative correlation with the physiological quality of the seeds and points to the loss of selectivity of cell membranes, further reinforcing the negative effects of deterioration on the physiologic quality of sunflower seeds.

\section{CONCLUSIONS}

Deterioration caused by accelerated aging leads to a reduction in germination and vigor of sunflower seeds, especially in lots of lower initial physiological quality. Deterioration affects the activity of the antioxidant enzymes (SOD, POX, and APX) of the seeds, mainly from $48 \mathrm{~h}$ of exposure to aging. Peroxidases are activated in sunflower seeds, mainly after two days of germination.

\section{ACKNOWLEDGMENTS}

To the Department of Agronomy of the Federal University of Viçosa (UFV). To the National Council for Scientific and Technological Development (CNPq) (Funding Code: 001), Coordination for the Improvement of Higher Education Personnel (CAPES) and Minas Gerais State Research Support Foundation (FAPEMIG).

\section{REFERENCES}

ABREU, L. A. D. S. et al. Deterioration of sunflower seeds during storage. Journal of Seed Science, 35: 240-247, 2013.

ANJUM, N. A. et al. Lipids and proteins major targets of oxidative modifications in abiotic stressed plants. Environmental Science and Pollution Research, 22: 4099-4121, 2015.

BAILLY, C. Active oxygen species and antioxidants in seed biology. Seed Science Research, 14: 93-107, 2004.

BAILLY, C. et al. Changes in malondialdehyde content and in superoxide dismutase, catalase and glutathione reductase activities in sunflower seeds as related to deterioration during accelerated aging. Physiologia Plantarum, 97: 104-110, 1996.

BALESEVIC-TUBIC, S. et al. Seed viability of oil crops depending on storage conditions. Helia, 33: 153-160, 2010.

BEAUCHAMP, C.; FRIDOVICH, I. Superoxide dismutase: improved assays and an assay applicable to acrylamide gels. Analytical Biochemistry, 44: 276-287, 1971. 
BONIECKA, J. et al. Potential biochemical, genetic and molecular markers of deterioration advancement in seeds of oilseed rape (Brassica napus L.). Industrial Crops and Products, 130: 478-490, 2019.

BRADFORD, M. M. A rapid and sensitive method for the quantitation of microgram quantities of protein utilizing the principle of protein-dye binding. Analytical Biochemistry, 72: 248-254, 1976.

BRASIL. Instrução Normativa $\mathbf{n}^{\circ} \mathbf{4 5}$. Diário Oficial da República Federativa do Brasil. Brasília: Poder Executivo, 20 set., seção I, p. 6, 2013.

BRASIL. Ministério da Agricultura, Pecuária e Abastecimento. Regras para análise de sementes. Secretaria de Defesa Agropecuária. Brasília: MAPA/ ACS, 2009. 395 p.

DE WIT, M.; GALVÃO, V. C.; FANKHAUSER, C. Light-mediated hormonal regulation of plant growth and development. Annual Review of Plant Biology, 67: 513-537, 2016.

EBONE, L. A.; CAVERZAN, A.; CHAVARRIA, G. Physiologic alterations in orthodox seeds due to deterioration processes. Plant Physiology and Biochemistry, 145: 34-42, 2019.

EL-MAAROUF-BOUTEAU, $H$. et al. DNA alteration and programmed cell death during ageing of sunflower seed. Journal of Experimental Botany, 62: 5003-5011, 2011.

FAOSTAT - Food and Agriculture Organization of the United Nations. Sunflower World Production. 2020 .

FAROOQ, M. A. et al. Acquiring control: The evolution of ROS-Induced oxidative stress and redox signaling pathways in plant stress responses. Plant Physiology and Biochemistry, 141: 353-369, 2019.

FINCH-SAVAGE, W. E.; BASSEL, G. W. Seed vigour and crop establishment: extending performance beyond adaptation. Journal of Experimental Botany, 67: 567-591, 2016.

KAPOOR, D. et al. Antioxidant enzymes regulation in plants in reference to reactive oxygen species (ROS) and reactive nitrogen species (RNS). Plant Gene, 19: 1-13, 2019.

KAR, M.; MISHRA, D. Catalase, peroxidase, and polyphenoloxidase activities during rice leaf senescence. Plant physiology, 57: 315-319, 1976.

LI, Y. et al. Changes in the mitochondrial protein profile due to ROS eruption during ageing of elm
(Ulmus pumila L.) seeds. Plant Physiology and Biochemistry, 114: 72-87, 2017.

MAGUIRE, J. D. Speed of germination-Aid in selection and evaluation for seedling emergence and vigor. Crop science, 2: 176-177, 1962.

MARCOS-FILHO, J. Seed physiology of cultivated plants. Londrina, PR: ABRATES, 2016. 616 p.

MARCOS-FILHO, J. Teste de envelhecimento acelerado. In: KRZYZANOWSKI, F. C. et al. (Eds.). Vigor de sementes: conceitos e testes. Londrina: ABRATES, 2020, cap. 4, p. 185-243.

MIN, C. W. et al. In-depth proteomic analysis of Glycine max seeds during controlled deterioration treatment reveals a shift in seed metabolism. Journal of Proteomics, 169: 125-135, 2017.

MITTLER, R. ROS are good. Trends in Plant Science, 22: 11-19, 2017.

MORAIS, T. C. et al. Physiological and antioxidant changes in sunflower seeds under water restriction. Journal of Seed Science, 42: e202042008, 2020.

MORSCHER, F. et al. Glutathione redox state, tocochromanols, fatty acids, antioxidant enzymes and protein carbonylation in sunflower seed embryos associated with after-ripening and ageing. Annals of Botany, 116: 669-678, 2015.

NAKANO, Y.; ASADA, K. Hydrogen peroxide is scavenged by ascorbate-specific peroxidase in spinach chloroplasts. Plant and Cell Physiology, 22: 867-880, 1981

NOCTOR, G.; REICHHELD, J. P.; FOYER, C. H. ROS-related redox regulation and signaling in plants. Seminars in Cell \& Developmental Biology, 80: 3 $12,2018$.

OLIVEIRA, A. M. S. et al. Accelerated aging for evaluation of vigor in Brachiaria brizantha 'Xaraés' seeds. Journal of Seed Science, 42: e202042006, 2020 .

PHAM, H. M. et al. Alternative oxidase (AOX) over -expression improves cell expansion and elongation in cotton seedling exposed to cool temperatures. Theoretical and Applied Genetics, 131: 22872298, 2018.

R CORE TEAM. R Development Core Team R: A Language and Environment for Statistical Computing, 2020.

RATAJCZAK, E. et al. Mitochondria are important determinants of the aging of seeds. International 
Journal of Molecular Sciences, 20: 1568, 2019.

SAHU, A. K. et al. Active oxygen species metabolism in neem (Azadirachta indica) seeds exposed to natural ageing and controlled deterioration. Acta Physiologiae Plantarum, 39: 197, 2017.

SZEMRUCH, C. et al. Ranges of vigor based on the electrical conductivity test in dehulled sunflower seeds. Research Journal of Seed Science, 8: 12-21, 2015. 